\title{
Nationwide Stature Estimation from Length of Sternum Measurements in Montenegrin Adolescents
}

\author{
Estimación de la Estatura a Nivel Nacional a Partir de la Longitud \\ de las Mediciones del Esternón en Adolescentes Montenegrinos
}

Marina Vukotic

VUKOTIC, M. Nationwide stature estimation from length of sternum measurements in Montenegrin adolescents. Int. J. Morphol., 38(6):1586-1590, 2020.

SUMMARY: The purpose of this research is to determine a regression equation for estimation of stature from length of sternum measurements. This research was carried out on 1001 subjects (504 male and 497 female) among the population of Montenegrin adolescents. The stature and length of sternum measurements were taken according to the ISAK protocol, and the data were analyzed statistically. Linear regression analysis determined the prediction of and length of sternum on the criterion variable a body height at the significance level of $\mathrm{p}<0.05$. These relations are presented in the form of scatter diagram. Thereby, we obtained the coefficient of determination, the multiple correlation coefficients, the partial correlation coefficient, the regression, t-test and standardized beta coefficient. The results of this research study confirmed that length of sternum reliably predicts stature in both sexes of Montenegrin adolescents and revealed a very useful finding for physical anthropologists and experts from related fields. It was confirmed that there is a correlation between length of sternum and body height (males: $33.1 \%$, females: $31.3 \%$ ). Therefore, length of sternum has proven to be a reliable predictor on the basis of which the actual body height can be estimated.

\section{KEY WORDS: Prediction; Anthropometry; Length of Sternum; Montenegrin.}

\section{INTRODUCTION}

Stature is natural heights of a person in an upright position. The anthropologists and forensic experts have given more importance to the various methods of stature estimation (Agnihotri et al., 2011) Stature or body height is one of the important and useful anthropometric parameter that determines the physical identity of an individual (Vukotic, 2018a,b). The research of the proportions in the relations of body proportions and the consequences of their variations enables us to have information of numerous fields of additional scientific research (Hickson \& Frost, 2003; Golshan et al., 2007). The physical growth of humans is mainly influenced by genetic and environmental factors (Chandra et al., 2009; Popovic, 2018). Different dimensions of the physical growth are mainly influenced by the genetic factor, whereas the influence varies depending on the sex, age, etc. (Gupta et al., 2003). Body height is the main anthropometric parameter for the estimation of individuals and is significant in many situations (Mohanty et al., 2001). Stature has a definite and proportional biological relationship with each and every part of the length of sternum, i.e. head, face, trunk and limbs.
In addition, it is necessary for the evaluation of child growth for the calculation of nutrition indices of children and adults (King, 2004), the prediction and standardisation of variables such as lung capacity, muscle strength, the standardisation of physical ability measures for the determination of a patient's proper dose, etc. (Ibegbu, 2013). Furthermore, it can be a good parameter for diagnosing persons with various anomalies and body height loss after doctor medicinal activity on the spine (Mohanty et al.), as well as for predicting its loss in the case of the elderly (Waghmare et al., 2010). However, it is not always possible to determine precisely the height of the body, especially including the cases, for example, paralysis, fracture, amputation and various, deformities such as scoliosis, lordosis and kyphosis (Golshan et al.; Grasgruber et al., 2018). In such cases, it is necessary to apply some other parameter for the estimation of body height. The prominent height of the Montenegrins is a fact which was promoted by European anthropology scientist more than 100 years ago. Robert V. Ehrich (Waghmare et al.) measured the Montenegrin population and obtained data indicating that the 
Montenegrins could possibly have the highest average in all of Europe. Moreover, a study conducted by Pineau et al. (2005) showed that the population of the Dinaric Alps is on average the highest in Europe.

Stature has a definite and proportional biological relationship with each and every part of the human body, i.e. length of forearm, length of hand, length of foot, length of sternum and length of scapula (King). This relationship helps a forensic scientist to calculate stature from dismembered and mutilated body parts in forensic examinations (Meadows \& Jantz, 1992). In order to conduct a comprehensive altitude survey, it is necessary to establish a reliable predator, the fact that length of sternum is one of the reliable predictors (Celbis \& Agritmis, 2006; Dayal et al., 2008) of body height is confirmed by a study conducted by the authors in Egypt (Zaher et al., 2011) which found a high linear correlation between body height and length of sternum. Positive correlation have been found between body height and length of sternum in different populations and a regression coefficient has been offered (Nagesh \& Kumar, 2006), however, the regression formula in one population is not always unique to another population and studies indicate the need to study population specificity (Bidmos, 2008). For this reason, it is very important to establish the relationship between body height and length of sternum in Montenegrins at the national level-which has not been done yet-primarily because in some cases it can be very important to use precisely this anthropometric measure to determine body height, due to the above mentioned reasons.

For this reason, it is very important to establish the relationship between body height and length of sternum in Montenegrins at the national level-which has not been done yet-primarily because in some cases it can be very important to use precisely this anthropometric measure to determine body height, due to the above mentioned reasons. So the authors of this study expect the specificities of length of sternum in the adolescent population of both sexes especially in Montenegro. Based on the research done so far, it can be observed that the estimation of body height in comparison with the length of sternum as the potential predictor differs among different racial and ethnic groups, so the aim of this study is to determine the prediction of the longitudinal measure of length of sternum in the adolescent population in Montenegro on criterion variable a body height, in both sexes separately.

\section{MATERIAL AND METHOD}

The sample in this research comprised 1001 adolescent, all of whom were in their final year of high school
(504 males, 497 females) from the territory of Montenegro. There were two reasons for the selection of this population group, as follows: the first is connected with the fact that an individual's growth stops at this age, while the second is connected with the fact that there is no body weight loss at this age. The average age of the male subjects was $18.68 \pm 0.35$ years (age span 18-20), while the average age of the female subjects was $18.70 \pm 0.33$ years (age span $18-20$ ). Also, it is important to point out that the authors excluded from the study adolescents with body deformities (scoliosis, kyphosis, lordosis, etc.), paralysis, fractures, amputations, and similar. The study complied with the Declaration of Helsinki.

Subjects which did not originate from the territory of Montenegro were also excluded from this research. According to Marfell-Jones et al. (2006), anthropometric measurements, including body height and length of sternum, were taken in compliance with the protocol of the International Society for the Advancement of Kinanthropometry (ISAK). The age of the subjects was determined by asking them to tell their date of birth.

Method of data processing. The statistical processing of the data was performed using the statistical programme (SPSS) 25.0. For both anthropometric variables, central and dispersive parameters were processed within the scope of basic statistics, as follows: range (minimum and maximum value), arithmetic mean and standard deviation. Linear regression analysis determined the prediction of length of sternum on the criterion variable a body height at the significance level of $p<0.05$. These relations are presented in the form of scatter diagram. Thereby, we obtained the coefficient of determination, the multiple correlation coefficients, the partial correlation coefficient, the regression, $\mathrm{t}$-test and standardized beta coefficient.

\section{RESULTS}

The results of anthropometric measurements for both sexes are shown in Table I. The average body height for males is $184.09 \pm 6.28$, ranked with minimum and maximum values of 163.2-202.4 centimetres, while the length of sternum amounted to $16.32 \pm 1.22$ centimetres. In the case of females, the average body height amounts to $170.27 \pm 5.41$ centimetres ranked with minimum and maximum values of 152.1-188.1 centimetres, while the length of sternum amounted to $15.10 \pm 1.06$ centimetres.

The results of the linear regression analysis are shown in Table II. In both sexes, the regression coefficients (R) are identical to the correlation coefficients from the previous 
analysis and are very high. The high values of the regression coefficient (males: 0.424; females: 0.418) imply that the prediction of length of sternum on stature is statistically significant, i.e. that length of sternum can predict stature in the case of the Montenegrin population of both sexes (males $\mathrm{t}=10.189 ; \mathrm{p}<0.000$, females $\mathrm{t}=10.249 ; \mathrm{p}<0.000)$. Which is confirmed by $\mathrm{R}$-coefficient ( $\mathrm{R}$ Square) of determination $\mathrm{R}$-coefficient (\%) for males is 33.1 and for females 31.3 . The first of these models was performed by including age as a covariate. Regression coefficient values imply that length of sternum significantly predicts stature in Montenegrin adolescents of both sexes.
Information on the effect of predictor variable on criterion variable tested through a regression-based procedure, whose values are shown through Beta coefficient of regression (males: 1.753; females: 2.201), and standard errors of the regression coefficient (males: .156; females: .235) show confirmation of statistically significant impact of predictor variable on the criterion variable in both sexes of Montenegrin adolescents (Table III).

The relationship between the measurements of length of sternum and stature among the above mentioned models is shown using a scatter diagram (Fig. 1).

Table I. Anthropometric measurements of the study subjects.

\begin{tabular}{lcc}
\hline \multirow{2}{*}{ Subjects } & $\begin{array}{c}\text { Body Height Range } \\
(\text { Mean } \pm \text { SD) }\end{array}$ & $\begin{array}{c}\text { Length of Sternum Subjects } \\
(\text { Mean } \pm \text { SD })\end{array}$ \\
\hline \multirow{2}{*}{ Male } & $163.2-202.4$ & $13.4-19.8$ \\
& $(184.09 \pm 6.28)$ & $(16.32 \pm 1.22)$ \\
Female & $152.1-188.1$ & $12.4-18.0$ \\
& $(170.27 \pm 5.41)$ & $(15.10 \pm 1.06)$ \\
\hline
\end{tabular}

Table II. Results of linear regression analysis where the length of sternum predicts the stature.

\begin{tabular}{lcccccc}
\hline Subjects & $\mathrm{R}$ & $\mathrm{R}$ Square (\%) & $\begin{array}{c}\text { Adjusted } \\
\text { R Square }\end{array}$ & $\begin{array}{c}\text { Std. Error of } \\
\text { the Estimate }\end{array}$ & t-value & $\mathrm{p}$-value \\
\hline Male & $.424^{\mathrm{a}}$ & .331 & .178 & 56.834 & 10.189 & $.000^{*}$ \\
Female & $.418^{\mathrm{a}}$ & .313 & .173 & 49.262 & 10.249 & $.000^{*}$ \\
\hline
\end{tabular}

Table III. Results of coefficients regression analysis where the length of sternum predicts the stature.

\begin{tabular}{llrrrr}
\multicolumn{2}{l}{ predicts the stature. } \\
\cline { 2 - 6 } Subjects & Coefficients & Std.Error & \multicolumn{2}{c}{$95 \%$ Confidence Interval } \\
& Beta & & Lewer & Upper \\
\hline Male & 1.753 & .156 & 1.457 & 2.056 \\
Female & 2.201 & .235 & 1.724 & 2.656 \\
\hline
\end{tabular}
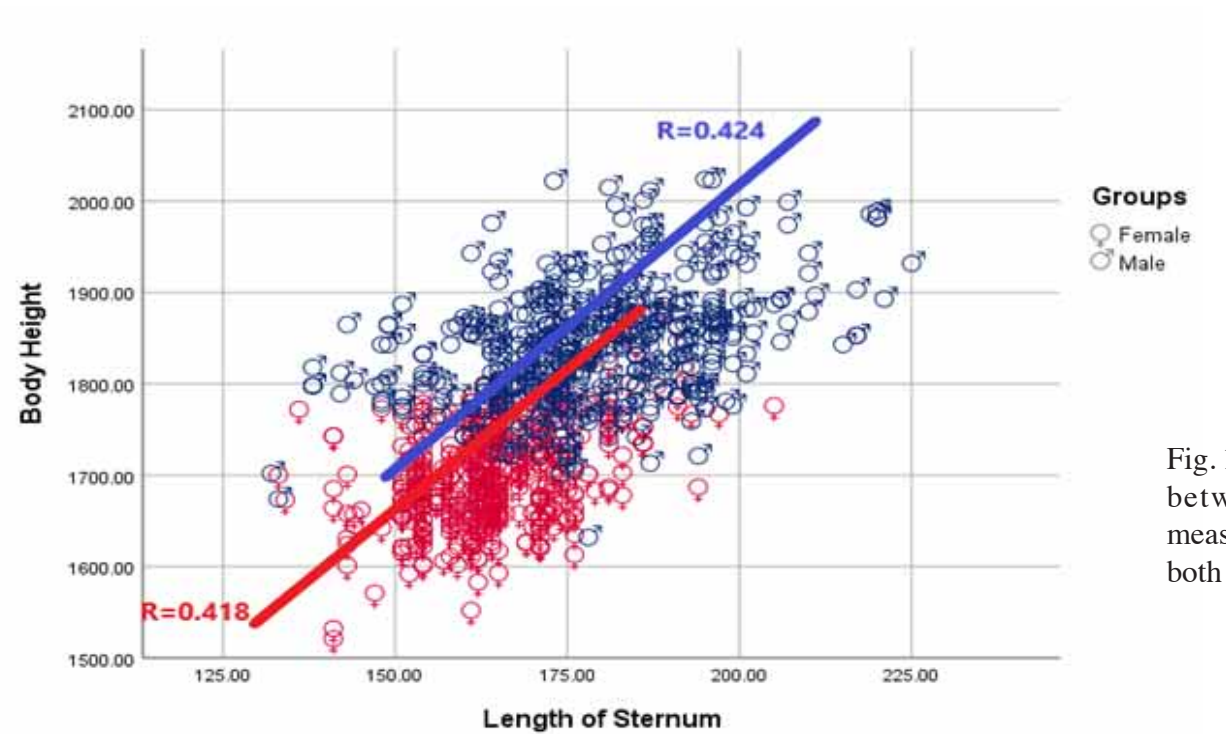

Fig. 1. Scatter diagram and relationship between length of sternum measurements and body height among both sexes. 


\section{DISCUSSION}

Many studies have confirmed that there is a specific correlation between stature and other potential parameters in different populations (Vukotic, 2018a,b). The results presented in this study will provide relevant data on the correlation between stature and length of sternum among the Montenegrin population at the national level. The average body height of the male subjects equals $184.09 \pm 6.28$ $\mathrm{cm}$ and is similar to the average height of the tallest nations in Europe. The average body height of Montenegrin female adolescents equals $170.27 \pm 5.41 \mathrm{~cm}$ and is similar to the average height among the tallest women in the world. The conducted research further elaborates the specific body proportions, primarily with the aim of improving the information on length of sternum as a reliable predictor of body height. Numerous studies have confirmed that length of sternum can account for $41 \%$ of variations in relation to stature (Meadows \& Jantz), which indicates a significant correlation between body height and other anthropometric parameters. The average length of sternum of Montenegrin adolescents equals (males: $16.32 \pm 1.22 \mathrm{~cm}$; females: $15.10 \pm 1.06 \mathrm{~cm}$ ), which confirms the main notion of this study that the population of Montenegro has specific body proportions. The research conducted by (Celbis \& Agritmis) has demonstrated similar values. It was confirmed that there is a correlation between length of sternum and body height (males: $36.9 \%$, females: $34.3 \%$ ). Therefore, length of sternum has proven to be a reliable predictor on the basis of which the actual body height can be estimated. The conducted research of length of sternum as a reliable body height predictor is of additional importance, because it is the only research of its kind that was conducted at the national level in accordance with proportional geographic sampling, which is also of crucial importance for future national and regional research of potential anthropometric predictors.

The results of this study can be used as baseline information for future research based on the Montenegrin adolescent population, and they confirm the need for the development of specific model when it comes to the analysis of both sexes of the Montenegrin population. It is important to note the comparison with the research on the body height of adolescents in Montenegro (Bjelica et al., 2012), which reveals a lower body height than the one among the subjects in this research. Based on the above, additional questions arise in regard to the potential causes of differences in stature, primarily because some authors presume that the body's growth and development do not stop at this age, (Loesch et al., 2005), because the full genetic potential of both sexes has not been achieved yet, and there are different economic and socioecological factors affecting it (Bjelica et al.), which was confirmed by this research. The period of secular growth, especially at the pace of growth, coincided with some studies conducted in the Australian population (Loesch et al.). This positive secular change seems to be the result of gradual changes in nutrition, health care and education in environmental and economic conditions (Boas et al., 1995). One possibility is that different factors potentially affect premature hormonal changes, i.e. the onset of puberty at an earlier age. Adolescents experience several types of maturation (Goran \& Gower, 2001). The complex series of biologic transitions are known as puberty, the most visible changes during puberty are growth in stature and development of secondary characteristics (Moran et al., 1999), However, many studies have used variations of Tanner's original description (Tanner, 1962). The majority of studies have combined the secondary sexual characteristics (Travers et al., 1995). Improvement of the method may validate its use in population-based studies. Sexual development and maturation is essential for the appropriate assessment of growth in children and adolescents, and is of paramount importance to the analysis of adequate growth and of adequate timing of pubertal development of an individual (Uwaifo et al., 2002).

The obvious limitation of this study is the fact that neither of the Montenegrin sexes have reached the full genetic potential and that a positive secular trend can significantly change the facts confirmed in this study. Based on this reasoning, a prerequisite is the establishment of adequate control of the facts, on a regular basis, as there are evidant expectation based on the european sample (Fredriks et al., 2005), which forsee secular changes in stature in the following decades; therefore, all current assumptions will be placed in question.

VUKOTIC, M. Estimación de la estatura a nivel nacional a partir de la longitud de las mediciones del esternón en adolescentes montenegrinos. Int. J. Morphol., 38(6):1586-1590, 2020.

RESUMEN: El propósito de este estudio fue determinar una ecuación de regresión para la estimación de la estatura a partir de la longitud del esternón. El análisis se llevó a cabo en 1001 sujetos (504 hombres y 497 mujeres) entre la población de adolescentes montenegrinos. Se tomaron medidas de la estatura y la longitud del esternón de acuerdo con el protocolo ISAK, y los datos se analizaron estadísticamente. El análisis de regresión lineal determinó la predicción y la longitud del esternón en la variable de criterio de la altura del cuerpo con nivel de significancia de $\mathrm{p}<0,05$. Las relaciones se presentan en forma de diagrama de dispersión. De este modo, obtuvimos el coeficiente de determinación, los coeficientes de correlación múltiple, el coeficiente de correlación parcial, la regresión, la prueba t y el coeficiente beta estandarizado. Los resultados de este estudio confirmaron que la longitud del esternón logra predecir la estatura en ambos sexos de adolescentes 
montenegrinos de manera confiable, y reveló un hallazgo útil para los antropólogos físicos y los expertos de áreas relacionadas. Se confirmó que existe una correlación entre la longitud del esternón y la altura del cuerpo (hombres: $33,1 \%$, mujeres: $31,3 \%$ ). Por lo tanto, la longitud del esternón ha demostrado ser un predictor confiable sobre la base de la cual se puede estimar la altura real del cuerpo.

PALABRAS CLAVE: Predicción; Antropometría; Longitud del esternón; Montenegrino.

\section{REFERENCES}

Agnihotri, A. K.; Kachhwaha, S.; Googoolye, K. \& Allock, A. Estimation of stature from cephalo-facial dimensions by regression analysis in IndoMauritian population. J. Forensic Leg. Med., 18(4):167-72, 2011.

Bidmos, M. A. Metatarsals in the estimation of stature in South Africans. $J$. Forensic Leg Med, 15:505-9, 2008.

Bjelica, D.; Popovic', S.; Kezunovic, M.; Petkovic., J; Jurak, G.; \& Grasgruber, G. Body height and its estimation utilizing arm span measurements in Montenegro adults. Anthropol. Noteb., 18(2):69-83, 2012.

Boas, S. R.; Falsetti, D.; Murphy, T. D. \& Orenstein, D. M. Validity of selfassessment of sexual maturation in adolescent male patients with cystic fibrosis. J. Adolesc. Health, 17(1):42-5, 1995.

Celbis, O. \& Agritmis, H. Estimation of stature and determination of sex from radial and ulnar bone lengths in a Turkish corpse sample. Forensic Sci. Int., 158(2-3):135-9, 2006.

Chandra, A.; Chandna, P; Deswal, S. \& Kumar, R. Ergonomics in the Office Environment. A Review. Chandigarh, Proceedings of the international Conference of Energy and Environment, 2009.

Dayal, M. R.; Steyn, M. \& Kuykendall, K. L. Stature estimation from bones of South African whites. S. Afr. J. Sci., 104(3-4):124-8, 2008

Fredriks, A. M.; van Buuren, S.; van Heel, W. J. M.; Dijkman-Neerincx, R. H. M.; Verloove-Vanhorick, S. P. \& Wit, J. M. Nationwide age references for sitting height, leg length, and sitting height/height ratio, and their diagnostic value for disproportionate growth disorders. Arch. Dis. Child., 90(8):807-12, 2005.

Golshan, M.; Crapo, R. O.; Amra, B.; Jensen, R. L. \& Golshan, R. Arm span as an independent predictor of pulmonary function parameters: validation and reference values. Respirology, 12(3):361-6, 2007.

Goran, M. I. \& Gower, B. A. Longitudinal study on pubertal insulin resistance. Diabetes, 50(11):2444-50, 2001

Grasgruber, P.; Popovic', S.; Bokuvka, D.; Davidovic', I.; Hrebíc`ková, S.; Ingrová, P.; Potpara, P.; Prce, S. \& Stračárová, N. The mountains of giants: an anthropometric survey of male youths in Bosnia and Herzegovina. R. Soc. Open Sci., 4(4):161054, 2018.

Gupta, C.; Palimar, V. \& Guru, P. Estimation of stature from the arm span of an individual in South Indian population. Ann. Bioanthropol., 4(1):179, 2003.

Hickson, M. \& Frost, G. A comparison of three methods for estimating height in the acutely ill elderly population. J. Hum. Nutr. Diet., 16(1):13$20,2003$.

Ibegbu, A. O. Association of hand length with height in Nigerian school children. J. Biol. Life Sci., 4(2):83-92, 2013.

King, K. A. A test of the Fully anatomical method of stature estimation. Am. J. Phys. Anthropol., 38:125, 2004.

Loesch, D. Z.; Stokes, K. \& Huggins, R. M. Secular trend in body height and weight of Australian children and adolescents. Am. J. Phys. Anthropol., 111(4):545-56, 2005.

Marfell-Jones, M.; Olds, T.; Stew, A. D. \& Carter, J. E. L. International
Standards for Anthropometric Assessment. Potchesfstroom, International Society for the Advancement of Kinanthropometry, 2006.

Meadows, L. \& Jantz, R. L. Estimation of stature from metacarpal lengths. J. Forensic Sci., 37(1):147-54, 1992.

Mohanty, S. P.; Babu, S. S. \& Nair, N. S. The use of arm span as a predictor of height: A study of South Indian women. J. Orthop. Surg. (Hong Kong), 9(1):19-23, 2001.

Moran, A.; Jacobs Jr., D. R.; Steinberger, J.; Hong, C. P.; Prineas, R.; Luepker, R. \& Sinaiko, A. R. Insulin resistance during puberty: results from clamp studies in 357 children. Diabetes, 48(10):2039-44, 1999.

Nagesh, K. R. \& Kumar, G. P. Estimation of stature from vertebral column length in South Indians. Leg. Med. (Tokyo), 8(5):269-72, 2006.

Pineau, J. C.; Delamarche, P. \& Bozinovic, S. Average height of adolescents in the Dinaric Alps. C. R. Biol., 328(9):841-6, 2005.

Popovic, S. Arm-span measurement as an alternative estimation of true height in Montenegrin young adults of both sexes: A national survey. Anthropol. Noteb., 24(1):53-67, 2018.

Tanner, J. M. Growth at Adolescence. 2nd ed. Oxford, Blackwell Scientific, 1962.

Travers, S. H.; Jeffers, B. W.; Bloch, C. A.; Hill, J. O. \& Eckel, R. H. Gender and Tanner stage differences in body composition and insulin sensitivity in early pubertal children. J. Clin. Endocrinol. Metab., 80(1):172-8, 1995.

Uwaifo, G. I.; Nguyen, T. T.; Keil, M. F.; Russell, D. L.; Nicholson, J. C.; Bonat, S. H.; McDuffie, J. R. \& Yanovski, J. A. Differences in insulin secretion and sensitivity of Caucasian and African American prepubertal children. J. Pediatr., 140(6):673-80, 2002.

Vukotic, M. Body height and its estimation utilizing arm span measurements in male and female adolescents from Danilovgrad and Cetinje. $J$. Anthropol. Sport Phys. Educ., 2(3):117-21, 2018a.

Vukotic, M. Body height and its estimation utilizing arm span measurements in male and female adolescents from northern region in Montenegro. J. Anthropol. Sport Phys. Educ., 2(3):73-7, 2018b.

Waghmare, V.; Gaikwad, R. \& Herekar, N. Estimation of the stature from the antropometric measurement of the hang length. Internet Biol. Anthropol., 4(2):1-5, 2010.

Zaher, J. F.; El-Ameen, N. F. M. \& Seedhom, A. E. Stature estimation using anthropometric measurements from computed tomography of metacarpal bones among Egyptian population. Egypt. J. Forensic Sci., 1(2):103-8, 2011.

Corresponding author:

Marina Vukotic, Teacher Assistant

University of Montenegro

Faculty for Sport and Physical Education

Narodne omladine bb

81400 Niksic

MONTENEGRO

Email: marina.vukotic82@gmail.com

Received: 26-04-2020

Accepted: 04-07-2020 